\title{
Interactive effect of dietary protein level and zilpaterol hydrochloride on feedlot performance and meat quality of steers
}

\author{
H.A. O'Neill, N.H. Casey ${ }^{\#}$ and E.C. Webb \\ Department of Animal and Wildlife Sciences, University of Pretoria, Pretoria 0002, South Africa
}

\begin{abstract}
Bonsmara type steers were used to determine the effect of dietary zilpaterol hydrochloride $(\mathrm{ZH})$ in combination with different dietary crude protein (CP) levels $(100,120$ and $140 \mathrm{~g} \mathrm{CP} / \mathrm{kg}$ ) on growth performance and meat quality. Treatment groups (T) consisted of 12 steers each. T1 $-100 \mathrm{~g} \mathrm{CP} / \mathrm{kg}+0.15$ $\mathrm{mg} \mathrm{ZH} / \mathrm{kg}$ live weight (LW); T2 - $120 \mathrm{~g} \mathrm{CP} / \mathrm{kg}+0.15 \mathrm{mg} \mathrm{ZH} / \mathrm{kg} \mathrm{LW} ; \mathrm{T} 3-140 \mathrm{~g} \mathrm{CP} / \mathrm{kg}+0.15 \mathrm{mg} \mathrm{ZH} / \mathrm{kg}$ $\mathrm{LW}$ and $\mathrm{T} 4-120 \mathrm{~g} \mathrm{CP} / \mathrm{kg}+0 \mathrm{mg} / \mathrm{kg} \mathrm{LW}$. Steers received the diets from an initial LW of $278 \mathrm{~kg}$ and fed to a target mass of $390 \mathrm{~kg}$. After a seven day ZH withdrawal period the steers were slaughtered and carcasses electrically stimulated. Samples from $m$. longissimus thoracis, $m$. semitendinosus and $m$. triceps brachii were kept in airtight polyethylene bags and matured for ten days at $4{ }^{\circ} \mathrm{C}$. Zilpaterol treatment increased the average daily gain (ADG) non-significantly (NS) by $9.6 \%$. Zilpaterol treatment improved feed conversion ratio (FCR) by $20 \%$ (NS). T2 showed a significant $39.4 \%$ improvement in FCR in comparison with T4. Warner-Bratzler shear force (WBSF) of $m$. semitendinosus and $m$. biceps brachii samples differed between ZH treated groups. Cooking loss (CL) for $m$. longissimus thoracis was lower for T2 in comparison with T1, $\mathrm{T} 3$ and T4. ZH treatment for 35 days, electrical stimulation and a maturation period of 10 days generally left the WBSF and CL unaffected while the FCR in combination with $120 \mathrm{~g} \mathrm{CP} / \mathrm{kg}$ improved significantly.
\end{abstract}

Keywords: $\beta$-agonist, growth efficiency, meat tenderness, cooking loss

${ }^{\#}$ Corresponding author. E-mail: norman.casey@up.ac.za

\section{Introduction}

The pharmocology and modes of action of beta adrenergic agonists (BAA) were reviewed in principle by Timmerman (1987) and since then the compound zilpaterol hydrochloride ( $\mathrm{ZH})$ has become commercially available as Zilmax ${ }^{\circledR}$. Beta adrenergic agonists activate the beta receptors in muscle and fat and the activation of beta receptors causes increased lipolysis, decreased lipogenesis and/or increased protein accretion (Mersmann, 1998). Beef carcass yield and muscle content increase with BAA supplementation as a result of decreased protein degradation and increased protein synthesis (Fiems, 1987).

The mRNA for the calpain protease inhibitor - calpastatin increases after BAA treatment (Killefer \& Koohmaraie, 1994). Suppression of the calpain proteases reduces the rate of protein degradation, resulting in increased muscle growth. The duration of exposure to $\mathrm{ZH}$ will have an effect on production efficiency as dry matter intake (DMI) will decrease and mass gain to feed intake ratio $(\mathrm{G}: \mathrm{F})$ will increase with a longer exposure interval (Vasconcelos et al., 2008).

The negative effects of calpastatin on the rate and extent of post mortem proteolysis and meat tenderness are documented by Koohmaraie et al. (1995). The occurrence of the Callipyge gene in cattle and sheep as well as data from some BAA trials provide evidence to associate negative effects of increased muscle hypertrophy (via reduced protein degradation) with decreased meat tenderness. However, all BAA are not equally potent and cells, tissues and individual animals vary greatly in expression of beta adrenergic receptors and the metabolic pathways linked to them. Available data on the effect of BAA treatment on meat quality characteristics are contradictory and require further investigating (Dunshea et al., 2005).

The use of a repartitioning agent as a metabolic modifier reduces fat in the whole body. In addition, genetic selection for leaner meat also reduced intramuscular fat levels. The perception is that meat is now tougher, less moist and has reduced flavour (Dunshea et al., 2005).

Since $\mathrm{ZH}$ reduces DMI, improves growth rate and has an anabolic effect on muscle protein, the question arises whether there is an interactive effect of feed protein level and $\mathrm{ZH}$ on feedlot performance and meat quality of steers. The aim of the study was to determine the effect of $\mathrm{ZH}$ in combination with different 
dietary crude protein (CP) levels on average daily gain (ADG), feed conversion ratio (FCR), Warner-Bratzler shear force (WBSF) and cooking loss (CL) of meat from feedlot steers.

\section{Material and Methods}

Bonsmara-type weaner steers were purchased from a commercial farmer. This breed is a medium maturity type bred for South African conditions and performs well in feedlots. The steers were adapted to the individual feeding system using Callen-Kamp system of feeding stations at the research feedlot. During the first week of adaptation they were fed good quality hay and during the second week were gradually adapted to a standard feedlot ration $(10.75 \mathrm{MJ} \mathrm{ME} / \mathrm{kg} \mathrm{DM})$ that also contained the ionophore, salinomycin. The steers were implanted with Revalor ${ }^{\circledR}$ and the processing involved vaccinating the steers with quarter evil/botulism combination vaccine OVI G111, anthrax vaccine OVI G112 and pasturella vaccine OVI G478. The steers were treated for internal parasites with Ivomec injectable and treated for external parasites with Drastic Deadline ${ }^{\circledR}$.

At the end of the adaptation period the steers were weighed and randomly allocated to four treatment groups, blocking for initial mass, the average starting weight of the 48 steers after the adaptation period being $278 \pm 20 \mathrm{~kg}$. The treatment diets were formulated on an iso-energetic basis to provide $10.75 \mathrm{MJ}$ $\mathrm{ME} / \mathrm{kg}$ DM with a variable CP content of 100,120 and $140 \mathrm{~g} / \mathrm{kg}$. Table 1 shows the treatments as was approved by the Ethics Committee of the Faculty of Natural and Agricultural Sciences, University of Pretoria.

Table 1 Dietary treatments of steers with a mean live weight of $278 \pm 20 \mathrm{~kg}$ containing 100, 120 and $140 \mathrm{~g}$ crude protein $(\mathrm{CP}) / \mathrm{kg}$ plus zilpaterol hydrochloride $(0.15 \mathrm{mg} \mathrm{ZH} / \mathrm{kg} \mathrm{LW})$ for the last 35 days of the feeding period

\begin{tabular}{|c|c|c|c|}
\hline Treatment & $\begin{array}{c}\text { Dietary metabolisable energy } \\
(\mathrm{MJ} \mathrm{ME} / \mathrm{kg} \mathrm{DM})\end{array}$ & $\begin{array}{l}\text { Dietary CP } \\
(\mathrm{g} / \mathrm{kg})\end{array}$ & $\begin{array}{c}\text { Zilpaterol hydrochloride } \\
\text { (mg ZH/kg LW) }\end{array}$ \\
\hline $\mathrm{T} 1$ & 10.75 & 100 & 0.15 \\
\hline $\mathrm{T} 2$ & 10.75 & 120 & 0.15 \\
\hline $\mathrm{T} 3$ & 10.75 & 140 & 0.15 \\
\hline $\mathrm{T} 4$ & 10.75 & 120 & 0 \\
\hline
\end{tabular}

Zilpaterol hydrochloride was administered as a top dressing for the last 35 days of the feeding period in addition to the treatment diets T1, T2 and T3. Average daily gain and FCR were recorded each day during the growth phase. The steers' intakes increased over time as did their live weight and therefore the $\mathrm{ZH}$ administration was calibrated each day to account for these differences in live weight.

After the 35-day ZH treatment period, ZH was withdrawn for seven days before the steers were sent to the abattoir. This was not required for $\mathrm{T} 4$ that received no $\mathrm{ZH}$, but the steers were kept on the feedlot ration together with the other treatment groups. The steers were slaughtered at a target live weight of approximately $390 \mathrm{~kg}$.

At attaining the assigned slaughter weight, an overnight fasting live weight was obtained. The steers were then re-fed and transported by road to a commercial abattoir where they were slaughtered the day after arrival. Only fresh water was available to steers in the holding pens.

Carcasses were electrically stimulated for 60 seconds, with a potential difference of 500 volts and a frequency of $12.5 \mathrm{~Hz}$ and classified as per SA Carcass Classification Standards. Warm carcass and cold carcass weights were recorded, following standard chilling overnight at $4{ }^{\circ} \mathrm{C}$. Representative samples from $m$. longissimus thoracis, $m$. semitendinosus and $m$. triceps brachii were collected at the abattoir and vacuum packed in polyethylene bags. These were matured for 10 days at $4{ }^{\circ} \mathrm{C}$. After the maturation period, the 
samples were frozen to $-20{ }^{\circ} \mathrm{C}$. Thawing was at room temperature for analyses. After thawing the $m$. longissimus thoracis, $m$. semitendinosus and $m$. triceps brachii, a core sample of approximately $180 \mathrm{~g}$ was taken from the centre of the muscles. Visible fat and connective tissue were removed. The core sample was patted dry with a paper towel, weighed, placed in a leak proof plastic bag, and suspended in a water bath at $70{ }^{\circ} \mathrm{C}$ for 1 hour. The bags were taken out of the bath and the samples, while still in the bags, were allowed to stand for 20 minutes after which they were removed, dried with a paper towel and re-weighed. The CL was then calculated by expressing the weight loss (moisture) as a percentage of the original weight. They were then placed back into their bags and refrigerated overnight at $4{ }^{\circ} \mathrm{C}$. Three $2.54 \mathrm{~cm}$ core samples were cut with the grain and used for shear force determination. A shear blade was attached to an Instron Model 1101. Three shear force values $(\mathrm{N})$ were measured on each core sample by shearing across the grain of the meat with a crosshead speed of $200 \mathrm{~mm} / \mathrm{min}$.

Every steer was fed and electrically monitored by means of Callen-Kamp controlled feeding system. Each steer was treated individually and used as a replicate in the analyses. Since unbalanced groups were left, the statistical procedures for unbalanced groups were used according to the SAS procedures (SAS, 1985). Test for differences between replicates was by the Fischer test.

\section{Results}

The pooled ADG for $\mathrm{ZH}$ treated steers was $1.44 \mathrm{~kg} /$ day which is $9.6 \%(\mathrm{P}>0.1)$ higher than that of the control group (1.30 kg/day). No differences were found in ADG between the groups fed different CP levels and $\mathrm{ZH}$ administration. The pooled FCR of the $\mathrm{ZH}$ treated steers was 6.07 which is $20 \%(\mathrm{P}>0.1)$ more efficient than that of the control group. T2 showed a FCR that was 39.4\% $(\mathrm{P}<0.1)$ more efficient than that of T4. No statistically significant differences were found between T1, T2 and T3. Overall, T2 showed a greater improvement in FCR which suggests that $120 \mathrm{~g} \mathrm{CP} / \mathrm{kg}$ and $\mathrm{ZH}$ administration was the most efficient.

For $m$. semitendinosus, there was a tendency $(\mathrm{P}<0.1)$ for a higher WBSF for $\mathrm{T} 1$ in comparison with T2. For $m$. longissimus, no statistically significant differences for WBSF were observed between any of the

Table 2 Least square mean ( \pm s.e.) of growth performance and meat quality of steers treated with zilpaterol hydrochloride in combination with 100,120 or $140 \mathrm{~g}$ crude protein $(\mathrm{CP}) / \mathrm{kg}$ feed

\begin{tabular}{|c|c|c|c|c|}
\hline & \multicolumn{4}{|c|}{ Treatment group } \\
\hline & $\mathrm{T} 1$ & $\mathrm{~T} 2$ & $\mathrm{~T} 3$ & $\mathrm{~T} 4$ \\
\hline \multicolumn{5}{|l|}{ Growth performance } \\
\hline Average daily gain (kg/day) & 1.47 & 1.42 & 1.44 & 1.30 \\
\hline Feed conversion ration (kg feed/kg growth) & $6.24^{\mathrm{ab}}$ & $5.48^{\mathrm{a}}$ & $6.48^{\mathrm{ab}}$ & $7.64^{\mathrm{b}}$ \\
\hline \multicolumn{5}{|l|}{ Meat quality } \\
\hline \multicolumn{5}{|l|}{ Shear force $(\mathrm{N})$} \\
\hline M. semitendinosus & $60.0^{\mathrm{a}}$ & $52.8^{\mathrm{b}}$ & $57.8^{\mathrm{ab}}$ & $59.3^{\mathrm{ab}}$ \\
\hline M. longissimus thoracis & 56.4 & 59.4 & 62.4 & 59.6 \\
\hline M. biceps brachii & $58.0^{\mathrm{b}}$ & $61.6^{\mathrm{b}}$ & $77.8^{\mathrm{a}}$ & $64.5^{\mathrm{ab}}$ \\
\hline \multicolumn{5}{|l|}{ Cooking loss (\%) } \\
\hline M. semitendinosus & 25.8 & 25.3 & 26.9 & 25.1 \\
\hline M. longissimus thoracis & $26.0^{\mathrm{b}}$ & $23.9^{\mathrm{a}}$ & $26.7^{\mathrm{b}}$ & $27.0^{\mathrm{b}}$ \\
\hline M. biceps brachii & 25.4 & 26.3 & 25.1 & 25.0 \\
\hline
\end{tabular}


groups. For $m$. biceps brachii, T3 had a significantly ( $\mathrm{P}<0.05)$ higher WBSF compared to T1 and T2. The results suggest that overall $\mathrm{ZH}$ treatment does not have any significant negative effect on WBSF. However, a high $(140 \mathrm{~g} / \mathrm{kg}) \mathrm{CP}$ regime coupled with $\mathrm{ZH}$ supplementation may have a negative effect in the $m$. biceps brachii. ZH treatment did not affect the $\mathrm{CL}$ of $m$. semitendinosus and $m$. biceps brachii. For $m$. longissimus thoracis, $\mathrm{T} 2$ had a lower $(\mathrm{P}<0.1) \mathrm{CL}$ when compared to $\mathrm{T} 1, \mathrm{~T} 3$ and $\mathrm{T} 4$. T4 did not differ from $\mathrm{T} 1$ and $\mathrm{T} 3$. The results suggest that $\mathrm{ZH}$ administration at $120 \mathrm{~g} \mathrm{CP} / \mathrm{kg}$ results in lower CL in meat from feedlot steers.

\section{Discussion}

Enhanced growth performance accounts for $55 \%$ of the net economic value of $\mathrm{ZH}$ as a benefit to the producer, while increased carcass yield accounts for $45 \%$ of the net value, which benefits the meat packer and retailer (Courtheyn et al., 2002).

In the study by Scheltens (1998) ADG was 13\% ( $\mathrm{P}<0.02)$ higher in $\mathrm{ZH}$ treated steers than the control group. FCR was 31\% ( $\mathrm{P}<0.0001)$ lower in ZH treated steers than the control group (Scheltens, 1998). In the study by Avendaño-Reyes et al. (2006), the inclusion of $60 \mathrm{mg} \mathrm{ZH/steer/day} \mathrm{to} \mathrm{the} \mathrm{diet} \mathrm{of} \mathrm{feedlot} \mathrm{steers}$ during the last 33 days of finishing, resulted in a $26 \%(\mathrm{P}<0.01)$ improvement in ADG and a considerable improvement $(\mathrm{P}<0.01)$ in $\mathrm{G}: \mathrm{F}$. In the study by Vasconcelos et al. $(2008)$, steers were treated with 8.33 $\mathrm{mg} / \mathrm{kg}$ of dietary DM basis ZH for 0, 20, 30 or 40 days before slaughter. ADG was greater for the average of the three $\mathrm{ZH}$ treated groups during the period in which $\mathrm{ZH}$ diets were fed $(\mathrm{P}<0.01)$ and for the overall feeding period $(\mathrm{P}=0.05)$. As duration of $\mathrm{ZH}$ feeding increased the DMI decreased and $\mathrm{G}: \mathrm{F}$ increased ( $\mathrm{P}<0.01)$. In the study by Montgomery et al. (2009) steers were treated with ZH during the final 35 days in a feedlot with $8.3 \mathrm{mg} \mathrm{ZH} / \mathrm{kg}$ (DM basis) and withdrawn from the diet for the last five or six days. Feeding $\mathrm{ZH}$ increased ADG $(\mathrm{P}<0.001)$ by $0.20 \mathrm{~kg}$ and $\mathrm{G}: \mathrm{F}(\mathrm{P}<0.001)$ by $0.029 \mathrm{~kg}$ growth $/ \mathrm{kg}$ feed. In the present study steers were supplemented with $\mathrm{ZH}$ on a live mass base and no significant differences in ADG were found between the groups with different CP levels. ZH treatment coupled with a CP level of $120 \mathrm{~g} / \mathrm{kg}$ showed a significant improvement in FCR. An inclusion rate of $120 \mathrm{~g} \mathrm{CP} / \mathrm{kg}$ proved to be more economically efficient.

WBSF provides an estimate of meat tenderness. Objective measurements such as WBSF and trained sensory panels provide data that enable scientists to compare various treatments to one another. It may not provide enough information on how well consumers will like a particular treatment, whether consumers will find a treatment acceptable, or whether consumers will prefer one treatment over another (Wheeler et al., 1997).

The duration of treatment with ZH influenced the meat quality parameters as studied by Strydom et al. (1999). When ZH was fed for 15 or 30 days, there were no negative effects on meat quality parameters, whereas feeding it for 50 days resulted in lower sensory tenderness and juiciness ratings for $m$. longissimus (Strydom et al., 1998; 1999). Feeding ZH for 35 days in the present study did not influence WBSF significantly, except for the group fed $140 \mathrm{~g} \mathrm{CP} / \mathrm{kg}$ at the $m$. biceps brachii which emphasises the muscle specific effect of BAA treatment.

Also, electrical stimulation helps prevent cold shortening by using up ATP before the onset stage of rigor mortis. The violent contraction of muscle as a result of electrical stimulation causes accelerated anaerobic glycolysis, which increases the rate of $\mathrm{pH}$ decline and reduces the overall time of rigor mortis. This in turn reduces the muscle's susceptibility to cold shortening. Electrical stimulation of beef produces significant positive effects on lean maturity, overall maturity and WBSF tenderness (Savell et al., 1978; Calkins et al., 1980).

\section{Conclusion}

Treatment with $\mathrm{ZH}$ for 35 days, stimulating the carcasses electrically coupled with a maturation period of 10 days could be a cost effective and efficient way to improve feed efficiency without any detrimental effect on meat quality.

\section{References}

Avendaño-Reyes, L., Torres-Rodríguez, V., Meraz-Murillo, F.J., Pérez-Linares, C., Figueroa-Saavedra, F. \& Robinson, P.H., 2006. Effects of two $\beta$-adrenergic agonists on finishing performance, carcass characteristics and meat quality of feedlot steers. J. Anim. Sci. 84, 3259-3265. 
Calkins, C.R., Savell, J.W., Smith, G.C. \& Murphey, C.E., 1980. Quality-indicating characteristics of beef as affected by electrical stimulation and postmortem chilling time. J. Food Sci. 45, 1330-1332.

Courtheyn, D., Le Bizec, B., Brambilla, G., De Brabander, H.F., Cobbaert, E., Van de Wiele, M., Vercammen, J. \& De Wasch, K., 2002. Recent developments in the use and abuse of growth promoters. Anal. Chim. Acta. 473, 71-82.

Dunshea, F.R., D'Souza, D.N., Pethick, D.W., Harper, G.S. \& Warner, R.D., 2005. Effects of dietary factors and other metabolic modifiers on quality and nutritional value of meat. Meat Sci. 71, 8-38.

Fiems, L.O., 1987. Effect of beta-adrenergic agonists in animal production and their mode of action. Ann. Zootech. 36, 271-290.

Killefer, H.J. \& Koohmaraie, M., 1994. Bovine skeletal muscle calpastatin: cloning, sequence analysis, and steady-state mRNA expression. J. Anim. Sci. 72, 606-614.

Koohmaraie, M., Killefer, J., Bishop, M.D., Shackelford, S.D., Wheeler, T.L. \& Arbona, J.R., 1995. Calpastatin-based methods for predicting meat tenderness. In: Expression of tissue proteinases and regulation of protein degradation as related to meat quality. Eds Ouali, A., Demeyer, D. \& Smulders, F., Utrecht, The Netherlands. pp. 395-412. (Cited by Koohmaraie et al., 2002).

Koohmaraie, M., Kent, M.P., Shackelford, S.D., Veiseth, E. \& Wheeler, T.L., 2002. Meat tenderness and muscle growth: is there any relationship? Meat Sci. 62, 345-352.

Mersmann, H.J., 1998. Overview of the effects of beta-adrenergic receptor agonists on animal growth including mechanism of action. J. Anim. Sci. 76,160-172.

Montgomery, J.L., Krehbiel, C.R., Cranston, J.J., Yates, D.A., Hutcheson, J.P., Nichols, W.T., Streeter, M.N., Bechtol, D.T., Johnson, E. \& TerHune, T., 2009. Dietary zilpaterol hydrochloride. I. Feedlot performance and carcass traits of steers and heifers. J. Anim. Sci. 87, 1374-1383.

SAS, 1985. SAS User's guide. SAS institute Incorporate, Raleigh, North Carolina.

Savell, J.W., Smith, G.C. \& Carpenter, Z.L., 1978. Beef quality and palatability as affected by electrical stimulation and cooler aging. J. Food Sci. 43, 1666-1677.

Scheltens, M.L., 1998. The effect of Zilpaterol and an anabolic steroid on growth performance, carcass and meat characteristics of feedlot steers. MSc (Agric) thesis, University of Pretoria, South Africa.

Strydom, P., Osler, E.A., Leeuw, K-J. \& Nel, E., 1998. The effect of supplementation period of a betaagonist (Zilpaterol) on growth performance, carcass and meat quality characteristics. In: 44th Int. Congress of Meat Science and Technology, Barcelona, Spain. pp. 894-895.

Strydom, P.E., Osler, E.A., Leeuw, K-J. \& Nel, E., 1999. The effect of supplementation period of a betaagonist (Zilpaterol), electrical stimulation and ageing period on meat quality characteristics. In: Proc. 45th Int. Congress of Meat Science and Technology, Yokohama, Japan. Vol. 2. pp. 58-59.

Timmerman, H., 1987. ß-adrenergics: Physiology, pharmacology, applications, structures and structureactivity relationships. In: Beta-agonists and their effects on animal growth and carcass quality. A publication of the Commission of the European Communities. Elsevier Applied Science. pp. 13-28.

Vasconcelos, J.T., Rathmann, R.J., Reuter, R.R., Leibovich, J., McMeniman, J.P., Hales, K.E., Covey, T.L., Miller, M.F., Nichols, W.T. \& Galyean, M.L., 2008. Effects of duration of zilpaterol hydrochloride feeding and days on the finishing diet on feedlot cattle performance and carcass traits. J. Anim. Sci. $86,2005-2015$.

Wheeler, T.L., Shackelford, S.D. \& Koohmaraie, M., 1997. Standardizing collection and interpretation of Warner-Bratzler shear force and sensory tenderness data. In: Proc. Recip. Meat Conf. pp. 50, 68-77. 